\title{
Sensors Electrochemical Principles and Applications
}

\author{
Dr. Rahadian Zainul, S.Pd., M.Si \\ Prof. Dr Illyas Md Isa \\ Dr Norhayati Hashim
}


UNDANG-UNDANG REPUBLIK

INDONESIA NO 19 TAHUN 2002

TENTANG HAK CIPTA

\section{PASAL 72}

\section{KETENTUAN}

\section{PIDANA SAKSI}

\section{PELANGGARAN}

1. Barangsiapa dengan sengaja dan tanpa hak mengumumkan atau memperbanyak suatu Ciptaan atau memberi izin untuk itu, dipidana dengan pidana penjara paling singkat 1 ( satu) bulan dan/atau denda paling sedikit Rp 1.000.000,00 (satu juta rupiah), atau pidana penjara paling lama 7 (tujuh) tahun dan/atau denda paling banyak Rp. 5.000.000.000,00 (lima milyar rupiah)

2. Barangsiapa dengan sengaja menyerahkan, menyiarkan, memamerkan, mengedarkan, atau menjual kepada umum suatu Ciptaan atau barang hasil pelanggaran Hak Cipta atau Hak Terkait sebagaimana dimaksud dalam ayat (1), dipidana dengan pidana penjara paling lama 5 (lima) tahun dan/atau denda paling banyak Rp 500.000.000,00 (lima ratus juta rupiah ). 


\section{BERKAH PRIMA}

Alamat: Jalan Datuk Perpatih Nan Sabatang 287, Air Mati, Solok Sumatera Barat.

\section{Anggota IKAPI Pusat}

No. Anggota : 016/SBA/18 tanggal 1 Agustus 2018

Cetakan Pertama,

Hak Cipta dilindungi oleh undang-undang.

Dilarang memperbanyak atau memindahkan sebagian atau seluruh isi buku ini dalam bentuk apapun. Secara elektronis maupun mekanis, termasuk memfotocopy, merekam, atau dengan teknik perekaman lainnya, tanpa izin tertulis dari penerbit

Tajuk entri utama : Rahadian,

\section{Sensors Electrochemical}

\section{Principles and Applications}

Edisi Pertama, cet. Ke-1 Padang: Berkah Prima, 2018

Editor : Tim editor

1 (satu) jilid; 14,8x21 cm (A5), Isi 170 hal. + (xviii )

ISBN:

Editor isi (Substansi): Prof Dr Syukri Arief, M.Sc Dr.Nasbahry Couto, M.Sn.. Desainer

Grafis : Annisa Awalliyah

Perwajahan: Tim Layout CV. Berkah Prima 


\section{PREFACE}

Alhamdulillah, a book called Sensor Electrochemical: Principles and Applications, was successfully compiled. Hopefully this book can be useful in the development of science, especially in the areas of Catalysts and Industrial Chemistry. All manuscripts compiled are the result of research and literacy conducted during the study of the first year of research 2019 and the study of Chemistry in Materials.

This Electrochemical Sensor: Principles and Applications book can be used by students and researchers interested in developing materials and catalysts. In this book there is a basis for making electrochemical sensors and materials integrally examined based on their respective parts and techniques.

This book contains various aspects of developing catalysts and advanced materials for handling waste, sensors, electrodes and other materials synthesis, including derivative materials. In this book, there is more emphasis on the engineering aspects of the latest journal reviews and research studies in various countries.

\section{Dr. Rahadian Zainul, S.Pd., M.Si.}




\section{CONTENTS}

Preface. ... $\mathrm{V}$

Contents. ..vi

I. Simultaneously determination of bisphenol $A$ and uric acid by zinc/aluminum-layered double hydroxide-2-(2,4-dichlorophenoxy) propionate paste electrode

II. Zinc layered hydroxide-sodium dodecyl sulphate-isoprocarb modified multiwalled carbon nanotubes as sensor for electrochemical determination of dopamine in alkaline medium

III. Zinc/aluminium-quinclorac layered nanocomposite modified multiwalled carbon nanotube paste electrode for electrochemical determination of bisphenol $A$ 